\title{
Invited review: Acid whey trends and health benefits
}

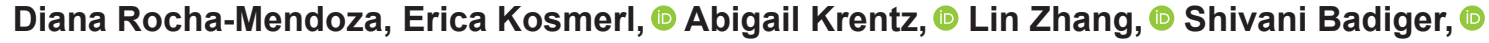

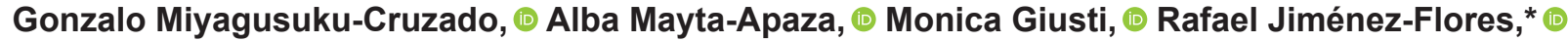 \\ and Israel García-Cano* [a \\ Department of Food Science and Technology, The Ohio State University, Columbus 43210
}

\section{ABSTRACT}

In recent years, acid whey production has increased due to a growing demand for Greek yogurt and acidcoagulated cheeses. Acid whey is a dairy by-product for which the industry has long struggled to find a sustainable application. Bulk amounts of acid whey associated with the dairy industry have led to increasing research on ways to valorize it. Industry players are finding ways to use acid whey on-site with ultrafiltration techniques and biodigesters, to reduce transportation costs and provide energy for the facility. Academia has sought to further investigate practical uses and benefits of this by-product. Although modern research has shown many other possible applications for acid whey, no comprehensive review yet exists about its composition, utilization, and health benefits. In this review, the industrial trends, the applications and uses, and the potential health benefits associated with the consumption of acid whey are discussed. The proximal composition of acid whey is discussed in depth. In addition, the potential applications of acid whey, such as its use as a starting material in the production of fermented beverages, as growth medium for cultivation of lactic acid bacteria in replacement of commercial media, and as a substrate for the isolation of lactose and minerals, are reviewed. Finally, the potential health benefits of the major protein constituents of acid whey, bioactive phospholipids, and organic acids such as lactic acid are described. Acid whey has promising applications related to potential health benefits, ranging from antibacterial effects to cognitive development for babies to human gut health. Key words: acid whey, health benefit, industrial trends, composition

\footnotetext{
Received June 7, 2020.

Accepted September 23, 2020.

*Corresponding authors: garciacano.1@osu.edu and jimenezflores.1@osu.edu
}

\section{INTRODUCTION}

The production of a variety of dairy products, including yogurts, fresh and soft cheeses, cream cheeses, and caseinates, yields an acidic by-product known as whey (Wherry et al., 2019). In general, the whey fraction contains approximately $55 \%$ of the nutrients from milk, including $20 \%$ of the total protein content and 85 to $95 \%$ of the original milk volume (Guimarães et al., 2010; Walsh, 2014). Whey is the serum phase of milk, or the liquid remaining after removal of fat and casein, which contains mostly soluble components, including lactose, soluble salts, and globular proteins, among others (Guimarães et al., 2010; Chandrapala et al., 2016). Moreover, liquid whey is characterized by its green-yellowish color, resulting from the presence of riboflavin (vitamin $\mathrm{B}_{12}$; González Siso, 1996; De Wit 2011). Conventionally, whey is classified into acid whey or sweet whey based on its processing conditions (Guimarães et al., 2010; De Wit, 2011; Ryan and Walsh, 2016). Sweet whey, the by-product of the production of most cheeses, typically has a $\mathrm{pH}$ around 6 to 7, and lower ash and higher protein contents compared with acid whey (González Siso, 1996). Sweet whey is collected after the coagulation of casein during the production of hard (ripened) cheese via rennet or enzymatic coagulation using a mixture of chymosin and pepsin (Rama et al., 2019; Wherry et al., 2019). In contrast, acid whey is the by-product of acid coagulation. Its processing involves either the activity of lactobacilli through fermentation or addition of organic acids such as citric, acetic, or lactic acids, or mineral acids such as hydrochloric or sulfuric acid (Ryan and Walsh, 2016). Specifically, acid whey is a by-product from production of acid-coagulated cheeses (cottage cheese, ricotta cheese, and others) and Greek yogurt. With growing Greek yogurt and cottage cheese production, pressure is on the dairy industry to develop innovative methods for upcycling acid whey in a sustainable manner (Zotta et al., 2020).

The dairy industry has long struggled to find an economically and environmentally sustainable application for acid whey (Zotta et al., 2020). Inherent challenges 
exist regarding the use of acid whey, due to its composition. Acid whey has a high biological oxygen demand, ranging from 52,400 to $62,400 \mathrm{mg} / \mathrm{L}$ for Greek yogurt acid whey (GAW) and 31,900 to $40,000 \mathrm{mg} / \mathrm{L}$ for cottage cheese acid whey (CAW), making it difficult to dispose into the environment without costly effects on the surrounding ecosystems (Menchik et al., 2019). Additionally, due to the high lactic acid content and low $\mathrm{pH}$, it is difficult to spray dry acid whey, as most of the lactose is converted to its crystalline structure. Similarly, the high content of calcium phosphate in acid whey results in extensive fouling of the equipment. Acid whey may be spray dried if it is neutralized or additives are added (Bylund, 2015). The challenges of disposing of acid whey complicate its valorization, and further research is needed into potential applications for this plentiful by-product. In this review, we describe and consider the industrial trends, uses, composition, functional properties, research applications, and multiple health benefits of acid whey, as it has increasing relevance and use in multiple industrial areas (Figure $1)$.

\section{INDUSTRIAL TRENDS}

The amount of acid whey produced in recent years has skyrocketed with the increased production of Greek yogurt. Since 2009, demand for Greek yogurt in the United States has increased due to health-conscious consumers desiring high-protein, low-fat, on-the-go products (Watson, 2014; Newhart, 2018). Currently, Greek yogurt controls over half of the United States yogurt market and was the most popular style of yogurt bought in 2019 (Mintel, 2019). During Greek yogurt production, 100 units of milk are converted to 33 units of yogurt and 67 units of acid whey (Watson, 2014; Erickson, 2017). In 2015, 771,000 tons of Greek yogurt were produced, along with nearly 1.5 million tons of acid whey (Erickson, 2017). On the other hand, during acid-coagulated cheese production, $1 \mathrm{~kg}$ of cheese generates $10 \mathrm{~L}$ of acid whey (Mollea et al., 2013). The European Union has the largest cheese market in the world and, as a result, a large production of acid whey. It is estimated that the acid whey production solely from cheese in the European Union is 40 million tonnes per year (Zotta et al., 2020). In addition, a recent resurgence of cottage cheese in the North American dairy industry is projected to increase, as the market for high-protein, convenient snacks and innovative dairy products continues to rise (Newhart, 2019; Tricoles, 2019). The increased demand for these products creates a supply of acid whey that must be either disposed of or repurposed.

The most common application of acid whey is on farmland. Acid whey can be used as a fertilizer that is either directly added to the soil or mixed with manure before being applied (Ketterings et al., 2017). The soil conditions, along with the nutrient composition, application rate, and $\mathrm{pH}$ of the acid whey, should be closely monitored during land application (Ketterings

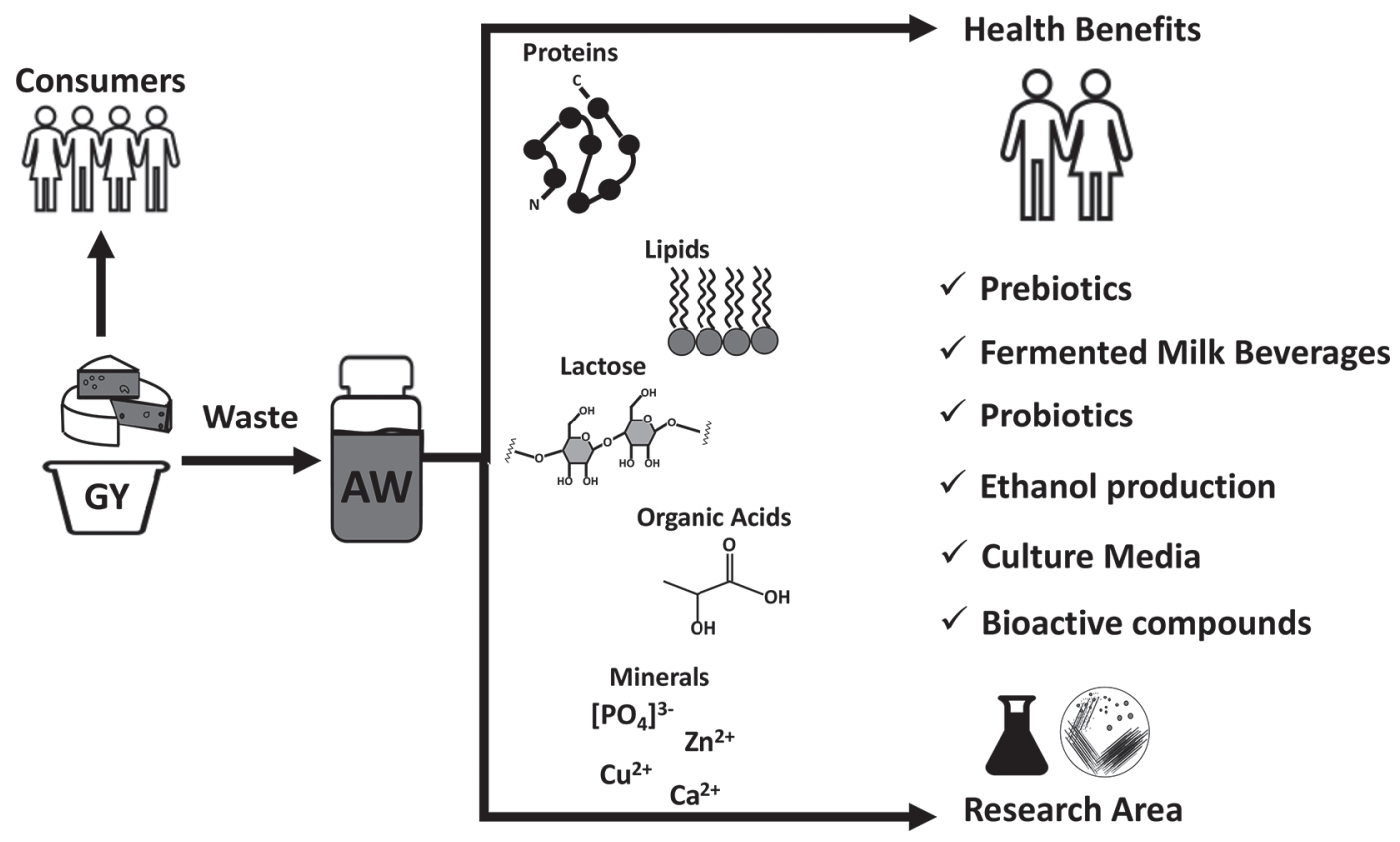

Figure 1. Outline of acid whey uses and its valorization. GY = Greek yogurt; AW = acid whey. 
et al., 2017). However, acid whey as a fertilizing agent must be limited due to the potential hazard of runoff. Another common use for acid whey is for animal feed. The acid whey can be mixed with silage and fed to livestock. However, only so much can be added as a wetting agent to the animal feed due to possibility of animal salt toxicity along with deterioration of animal stalls (Shurson, 2009). Acid whey can also be anaerobically digested into combustible fuel such as methane gas, which in turn can be used as an energy source (Erickson, 2017).

In recent years, environmentally conscious dairy food companies have been working to develop a sustainable solution for acid whey. These efforts range from isolating valuable components from acid whey to filtering it to reduce costs (Smithers, 2015). Chobani and Danone have made commitments to finding better handling practices for acid whey (Astley, 2013). Table 1 summarizes how companies are managing their acid whey production and management (Astley, 2013). Companies are trying to use the acid whey at their facilities rather than sending it to farms. For example, in 2014, Chobani installed a reverse-osmosis filtration system on-site to recover water from the acid whey, and ultimately reduced transportation costs of the concentrated whey (Watson, 2014). The recovered water is subsequently processed and reused. According to Chobani's 2019 sustainability report, they recycle $100 \%$ of the whey produced. General Mills installed an on-site biodigester to convert the acid whey into combustible biogas that can be used for energy (Watson, 2014). At the General Mills Yoplait facility in Murfreesboro, Tennessee, $10 \%$ of the plant's energy is supplied by the methane gas from the biodigester (Erickson, 2017). The business benefits of repurposing acid whey are tangible.

Companies are racing to be the first to develop the most environmentally conscious method for handling acid whey, while also returning a profit of their own. General Mills has been a leader in these patented ef- forts. They have developed a method for creating a neutralized yogurt whey concentrate with a $\mathrm{pH}$ of at least 6.0 (Smith et al., 2014). This concentrate can replace sweet whey in a variety of food products as a bulking agent or nutrient fortifier (Smith et al., 2014). In addition, General Mills has also developed a method for creating soluble fiber from acid whey, through enzymatic processes to convert lactose into an oligosaccharide (González and Smith, 2014). This soluble fiber may be applied in a variety of products, such as cereals or baked goods. Similarly, Danone has developed patented methods for generating acid whey with a more stable lactose content to allow for better isolation of the lactose (De La Cruz and Saint-Denis, 2016). The desire for sustainable applications of acid whey among dairy processing companies is immense.

In an alternative approach, companies such as Arla Foods Ingredients and Ultima Foods are exploring methods for minimizing the production of acid whey in the first place. Arla Foods Ingredients advertises the addition of their proprietary Nutralic milk proteins to eliminate the whey separation step during production, resulting in $100 \%$ yield of Greek yogurt product (Despain, 2013; Watson, 2014; Arla Foods Ingredients, 2019). Similarly, Ultima Foods has developed new processing methods for creating an ultra-filtered Greek yogurt that produces less acid whey than traditional Greek yogurt (Astley, 2013; Erickson, 2017). As industrial producers of Greek yogurt and cottage cheese try to remain accountable for their production of acid whey by using it in innovative ways, the use of acid whey in academia has increased, which is further addressed in the following sections of this review.

\section{ACID WHEY COMPOSITION}

With the help of modern technology, there has been a growing realization that acid whey is a valuable dairy stream, with functional proteins and peptides, lactose,

Table 1. Acid whey industrial commercialization trends

\begin{tabular}{ll}
\hline Acid whey application & Positive outcome \\
\hline Utilize reverse-osmosis filtration on acid whey ${ }^{1}$ & $\begin{array}{l}\text { Concentrated whey is less expensive to transport, reuse of water } \\
\text { Consistent source of lactose for isolation } \\
\text { Modified acid whey with stable lactose content }\end{array}$ \\
Utilize biodigester to convert acid whey & $\begin{array}{l}{ }^{2} \\
\text { Provides energy }\end{array}$ \\
Neutralize acid whey & Expands use of acid whey in food products \\
Utilize acid whey lactose to create a soluble fiber & Expands use of acid whey in food products \\
Utilize protein solution to minimize acid whey production ${ }^{4}$ & Less acid whey produced, increased product yield \\
Utilize ultrafiltration to minimize acid whey production ${ }^{5}$ & Less acid whey produced, increased product yield \\
\hline${ }^{1}$ Chobani (Norwich, NY). & \\
${ }^{2}$ Danone (Paris, France). & \\
${ }^{3}$ General Mills (Minneapolis, MN). & \\
${ }^{4}$ Arla Foods Ingredients (Viby, Denmark). & \\
${ }^{5}$ Ultima Foods (Quebec, Canada). &
\end{tabular}


lipids, vitamins, and minerals (Bylund, 2015). Its composition depends on several factors, such as the source of the milk, type of cheese or yogurt being processed, milk thermal treatment, storage after milking, and more (Lucas et al., 2006). Even the acid whey collected from the same source under identical processing conditions can have different protein contents across seasons (Lievore et al., 2015). Similarly, acid whey from GAW and CAW are compositionally different. In general, GAW has a lower content of ash, total solids, lactose, and lactic acid, and consequently has higher acidity than CAW, whereas CAW typically has higher protein content. Lipids are generally the same in both CAW and GAW because both are produced from skim milk. Due to its specific properties, acid whey has been used for drink production, such as vinegar beverages, with a focus on health benefits (Zotta et al., 2020). Whereas CAW has been used for production of functional beverages and bio-packaging (Zotta et al., 2020), GAW has been used produce glycine betaine and trehalose for applications in the food, agriculture, and pharmaceutical industries (Kar et al., 2015; Wherry et al., 2019; Zotta et al., 2020). Table 2 shows the approximate composition of acid whey from different sources (Bylund, 2015; Lievore et al., 2015; Menchik et al., 2019).

\section{ACID WHEY APPLICATIONS AND USES}

\section{Applications in Fermented Milk Beverages}

Due to its high nutritional composition, acid whey has great potential to be used as a main component in fermented milk formulation. Aimed at producing fermented milk drinks similar to yogurt, mixing acid whey with milk is technically viable. However, meeting consumers' demands in function of flavor and health is also a crucial factor in use of acid whey for production of fermented milk beverages. The sour and salty taste of acid whey is the first challenge in incorporating acid whey into food products (Lievore et al., 2015). Additionally, acid whey is not a standardized product, and composition variations will also affect the odor, flavor, and aftertaste of the final product (Villarreal, 2017). Thus, if the objectionable flavor of acid whey can be masked by the addition of other ingredients, including fruit flavor extracts and sweeteners, use of acid whey in food applications may increase (Villarreal, 2017). Lievore et al. (2015) used milk acid whey from Petit Suisse-type cheese production to replace all of the water in the original formulation of a commercial Brazilian-type fermented milk beverage. In their formulation, they added sucrose syrup, citric fruit aroma, and orange juice to mask the aroma generated during base fermentation. Incorporation of these flavor ingredients was suggested to compensate for the negative effects of acid whey addition and fermentation time reduction on the sensory quality of the final product. Although the comparison test indicated that no sample was evaluated as "better than the standard," the acceptance test showed $90 \%$ acceptance of the experimental product, and around $54 \%$ of consumers who participated in the sensory evaluation "would certainly" buy the product. In general, all of the sensory analysis results were favorable, and the commercial use of acid whey to replace water in the formulation could reduce water consumption, decrease fermentation time, and result in a more consistent and nutritive product (Lievore et al., 2015). In contrast, Villarreal (2017) did not add any extra

Table 2. Approximate composition of acid whey ${ }^{1}$

\begin{tabular}{|c|c|c|c|c|}
\hline \multirow[b]{3}{*}{ Component } & \multicolumn{4}{|c|}{ Source of acid whey (reference) } \\
\hline & \multirow{2}{*}{$\frac{\mathrm{HCl} \text { acid casein }}{\text { (Bylund, 2015) }}$} & Greek-style yogurt & Cottage cheese & Petit Suisse-type cheese \\
\hline & & (Menchik et al., 2019) & (Menchik et al., 2019) & (Lievore et al., 2015) \\
\hline $\mathrm{pH}$ & $4.3-4.6$ & $4.21-4.48$ & $4.35-4.41$ & 4.37 \\
\hline Acidity & NR & $0.42-0.53 \%$ & $0.28-0.31 \%$ & $0.61 \%(\mathrm{wt} / \mathrm{vol})$ \\
\hline Lipid & $0.04 \%$ & $0-0.01 \%$ & $0.01 \%$ & $0.09 \%(\mathrm{wt} / \mathrm{vol})$ \\
\hline Protein & $0.55 \%$ & $1.71-3.71(\mathrm{mg} / \mathrm{g})$ & $1.65-5.05(\mathrm{mg} / \mathrm{g})$ & $0.84 \%(\mathrm{wt} / \mathrm{vol})$ \\
\hline Ash & $0.80 \%$ & $0.64-0.75 \%(\mathrm{wt} / \mathrm{wt})$ & $0.33-0.42 \%(\mathrm{wt} / \mathrm{wt})$ & $0.61 \%(\mathrm{wt} / \mathrm{vol})$ \\
\hline Water content & $93.5 \%$ & $93.8-94 \%(w t / w t)$ & $96.3-96.7 \%(\mathrm{wt} / \mathrm{wt})$ & $94.44 \%(\mathrm{wt} / \mathrm{vol})$ \\
\hline Total solids & $6.50 \%$ & $6-6.2 \%(\mathrm{wt} / \mathrm{wt})$ & $3.3-3.7 \%(\mathrm{wt} / \mathrm{wt})$ & $5.57 \%(\mathrm{wt} / \mathrm{vol})$ \\
\hline Lactose & $4.90 \%$ & $3.33-3.5 \%$ & $1.99-2.13 \%$ & $4.18 \%(\mathrm{wt} / \mathrm{vol})$ \\
\hline Lactic acid & $0.4 \%$ & $0.64-0.65 \%$ & $0.37 \%$ & $\mathrm{NR}$ \\
\hline Calcium & $0.12 \%$ & $120-128(\mathrm{mg} / 100 \mathrm{~g})$ & $68.3-70.7(\mathrm{mg} / 100 \mathrm{~g})$ & NR \\
\hline Phosphorus & $0.07 \%$ & $66.5-69.2(\mathrm{mg} / 100 \mathrm{~g})$ & $46.3-48.9(\mathrm{mg} / 100 \mathrm{~g})$ & NR \\
\hline Sodium & $0.05 \%$ & $37.6-41.9(\mathrm{mg} / 100 \mathrm{~g})$ & $21.6-23.1(\mathrm{mg} / 100 \mathrm{~g})$ & NR \\
\hline Potassium & $0.16 \%$ & $156-169(\mathrm{mg} / 100 \mathrm{~g})$ & $90.8-95.2(\mathrm{mg} / 100 \mathrm{~g})$ & NR \\
\hline Chloride & $0.11 \%$ & $0.078-0.11(\mathrm{mg} / 100 \mathrm{~g})$ & $\leq 0.06(\mathrm{mg} / 100 \mathrm{~g})$ & NR \\
\hline
\end{tabular}

${ }^{1} \mathrm{NR}=$ not reported in original literature. 
flavor ingredients to their acid whey fermented product but used mango-flavored yogurt as the fermentation base. In this study, no significant difference was detected between the $45 \%$ acid whey-added sample and the $45 \%$ water-added sample regarding the preference test and overall liking scores; however, adding flavor ingredients might mask the sour and salty taste of acid whey (Villarreal, 2017). In another study with no added flavor ingredients, the flavor of the product was modified by 2 starter cultures: Lactobacillus acidophilus LA-5 and Bifidobacterium animalis ssp. lactis Bb-12 (Skryplonek and Jasińska, 2015; Skryplonek et al., 2019). The sensory test indicated that all samples had an intensive sour taste, but $L$. acidophilus LA-5 provided better organoleptic qualities than B. animalis Bb-12. Over 3 wk of storage, deterioration of taste and smell was also observed in all samples. Overall, none of these studies performed direct tests on the effects of flavor ingredients on the overall liking toward the acid wheyadded product, but the influence of flavor ingredients and starter cultures can be modified and monitored in future studies to make acid whey-supplemented beverages more attractive.

Change in texture is another challenge that should be considered when adding acid whey to prepare fermented milk products with similar characteristics to existing products. Lievore et al. (2015) found that preference levels for their fermented milk product with acid whey from the production of Petit Suisse-type cheese were negatively influenced by the low viscosity of the product. Replacing milk with acid whey can result in products with lower viscosities. Skryplonek and Jasińska (2015) combined acid whey from Twaróg cheese and milk in a 1:1 ratio to produce a fermented milk product similar to yogurt. However, their products had low appearance assessment due to syneresis caused by whey separation. The consistency of a fermented milk product is dependent on casein gel formation (Lievore et al., 2015). Because casein is almost absent in acid whey, replacing part of the milk with acid whey decreases the strength of the gel and viscosity of the product (Skryplonek and Jasińska, 2015). To improve the texture, Skryplonek et al. (2019) added more milk solids into the product either by replacing $25 \%$ of milk using $25 \%$ condensed milk or by adding $5 \%$ (wt/wt) skim milk powder into the product. Although syneresis was reduced, it still occurred over longer storage (Skryplonek and Jasińska, 2015; Skryplonek et al., 2019). Another study added $0.4 \%$ stabilizer, resulting in products with high viscosity and $100 \%$ water-holding capacity for all samples tested (Villarreal, 2017). Additionally, the study also indicated that homogenization after fermentation could improve the physical stability of the product and provide a smoother mouthfeel. Also, Lievore et al. (2015) prepared a fluid beverage in which acid whey replaced water, resulting in a more consistent product. When developing acid whey-supplemented fermented milk products, the addition of a stabilizer, the homogenization processing, and the beverage type should be taken into consideration to compensate for the effects caused by texture change.

\section{Use of Acid Whey for Cultivation of Microorganisms}

Using acid whey for cultivation of microorganisms becomes another alternative because it not only reduces the biological oxygen demand of acid whey by 90 to $95 \%$, but it also produces value-added bio-ingredients for food industries. Acid whey has been filtered and sterilized using microfiltration to cultivate different yeast strains (Dudkiewicz et al., 2016). Lactic acid bacteria (LAB) biomass also has numerous applications in food and pharmaceutical industries (MondragónParada et al., 2006). Lactic acid bacteria have complex nutritional requirements, especially the need for nitrogen (Benaissa et al., 2017). Currently, commercial media, such as de Man, Rogosa, and Sharpe (MRS) and M17, are designed for LAB cultivation, and usually have high protein contents with supplemented yeast extract or protein lysates (Kurmaci et al., 2015). However, the high cost of these media limits their use to specific laboratory conditions and has led to research on optimization of culture media for LAB. Whey contains lactose, vitamins, and minerals that can improve the physiological activity of cultivated cells, so using whey in LAB cultivation is another value-added application. So far, few publications have investigated the use of acid whey to prepare LAB culture medium. One study supplemented deproteinized and filtered sweet whey with $\mathrm{MgSO}_{4}, \mathrm{MnSO}_{4}$, and various concentrations of yeast extract and tomato juice to cultivate LAB (Benaissa et al., 2017). An acid whey-based medium supplemented with $30 \%$ tomato juice and $1 \%$ yeast extract can also produce a comparable amount of LAB biomass to that obtained from the MRS medium (Mondragón-Parada et al., 2006). The compositional differences between acid whey and sweet whey should be considered: LAB biomass production, using acid whey, usually contains a higher acidity level and salt content, and lower lactose and protein concentration, compared with sweet whey (Alsaed et al., 2013).

\section{Use of Acid Whey in Biofuel Production}

Another important application of acid whey is the use of lactose as a substrate to produce valuable compounds through fermentation. From fermentation, different bio-products can be obtained, such as ethanol, 
organic acids, biogas (methane), hydrogen, amino acids, and vitamins, among other compounds (Guimarães et al., 2010). During this process, lactose is directly consumed as a carbon source by microorganisms that produce value-added compounds.

Ethanol production from acid whey is economically competitive compared with other process. However, to obtain a better result, the acid whey must be processed, using ultrafiltration or reverse osmosis, or both, to concentrate the lactose. Microorganisms such as Kluyveromyces lactis, Kluyveromyces marxianus, and Candida pseudotropicalis have been used for this purpose (Das et al., 2016). Kluyveromyces marxianus yeast has been used to obtain ethanol from anaerobic fermentation of acid whey: in $13 \mathrm{~h}$ of incubation, $97 \%$ of the expected theoretical value is obtained (Sansonetti et al., 2009). Under anaerobic conditions, incubation of $K$. marxianus at temperatures between 33 and $38^{\circ} \mathrm{C}, \mathrm{pH}$ between 4.7 and 5.7, and lactose concentration between 50 and $108 \mathrm{~g} / \mathrm{L}$, provides a $90 \%$ ethanol yield from acid whey (Diniz et al., 2014).

\section{Use of Lactose and Minerals from Acid Whey}

Compared with sweet whey, the higher mineral content of acid whey poses challenges for both applications and disposal (Jelen, 2011). The average lactose contents of GAW and CAW are 3.5 and $2.5 \%$, respectively (Menchik et al., 2019). In general, the lactose content in acid whey is higher than that of sweet whey. The mineral composition also differs between acid and sweet whey. Acid whey contains significantly higher calcium, phosphorous, zinc, and copper. However, sweet and acid whey do not vary significantly in potassium, aluminum, magnesium, manganese, sodium, and boron. The average percentages by weight of calcium and phosphorous in acid whey (dry basis) are reported as 1.12 and 1.78, respectively (Menchik et al., 2019). Due to acid whey being recognized for its potential as a rich mineral source, innovative approaches have been applied to its processing. For example, the Center for Dairy Research at the University of Wisconsin, Madison, concentrated the lactose in acid whey using nanofiltration for potential use as a sweetener (Erickson, 2017). Due to its content of lactose, minerals, and amino acids, other applications of acid whey include but are not limited to fermented foods, sports beverages, snacks, and infant formula. Pretreatment of acid whey, such as demineralization and deacidification, is performed to facilitate easier drying or concentration and to reduce its stickiness. This pretreatment can be achieved via electrodialysis or nanofiltration. Electrodialysis has been shown to demineralize and deacidify GAW at greater rates (67 and 44\%, respectively) than nanofiltration (38 and
$34 \%$, respectively); however, electrodialysis results in significant membrane scaling, suggesting that nanofiltration may be a better long-term alternative (Dufton et al., 2018; Sunkesula et al., 2019). Moreover, calcium and phosphate recovery from acid whey not only reduces the risk of equipment fouling during drying but also provides an opportunity to obtain milk mineral ingredients for food applications (Almécija et al., 2009; Anema, 2009). A solid-liquid hydrocyclone is one of the many methods that can be used for this purpose (Crowley et al., 2019).

Rich in minerals, acid whey concentrated using a vacuum scraper concentrator can be used as a sugar replacement in bakery and confectionary food products (Alsaed et al., 2013). Fifty grams of concentrated acid whey fulfilled 114, 34, 25, 22, 20, and $18 \%$ of the recommended daily intakes of sodium, zinc, copper, calcium, magnesium, and potassium, respectively. Lactose-hydrolyzed acid whey has also been used as a sugar replacer at a level of $25 \%$ in products such as French bread, cherry cake, and kunafah syrup (Alsaed and Hadadin, 2012). Hydrolysis of lactose can be carried out using immobilized $\beta$-galactosidase, which has higher sweetness and higher solubility. $\beta$-Galactosidase is traditionally used for pretreatment of milk in the manufacturing of candies and fermented products (Husain, 2010). This step leads to elevated sweetness, solubility, and a decrease in the fermentation period. This application can be further extended to acid whey incorporation in confectionary products for improved sensorial properties and also in diverse fermentations. It is also important to note that fewer microorganisms are capable of using lactose as a source of carbon compared with those able to metabolize glucose and galactose (González Siso, 1996). Therefore, the use of lactose-hydrolyzed acid whey in bioprocesses may lead to a more viable and microbially rich fermentation capable of producing metabolites far more diverse and abundant than unhydrolyzed acid whey (Coté et al., 2004; Koutinas et al., 2009). Simple replacement of water with acid whey in milk fermentation can also lead to a reduction in fermentation periods due to the presence of lactose and other solids as a source of energy (Lievore et al., 2015).

Apart from being used in food products directly, acid whey can also be used to obtain various valorized products due to its lactose content. One such product is ethanol, which can be obtained by lactose fermentation using lactose-fermenting organisms such as $K$. marxianus. However, the efficiency of these organisms to produce ethanol is much lower than that of glucosefermenting microbes such as Saccharomyces cerevisiae (Terrell et al., 1984). Thus, an extra step of breaking down lactose to glucose and galactose can be applied 
using enzyme hydrolysis with $\beta$-galactosidase; however, this method is rather expensive for ethanol production (Coté et al., 2004). Alternatively, the breakdown of lactose can be done by acid-catalyzed hydrolysis, with the right choice of acids to minimize the formation of unwanted hydrolysis products. The process is well defined for pure glycosides, and further research is needed to optimize the process for acid whey. Efforts are also made to use genetically modified yeast or Escherichia coli strains for ethanol production, but further research is required for this method to be applied on an industrial scale (Pasotti et al., 2017).

Xanthan gum is another valorized product worth mentioning due to the ability of the fermenting microorganism Xanthomonas campestris to almost completely utilize glucose and galactose obtained from lactose hydrolysis in acid whey (Andrew, 1977). Most of the commonly used yeast species, on the other hand, metabolize glucose to a greater extent than galactose, making the process rather inefficient. Lactitol, lactulose, and lactosylurea are some other products that have been researched and produced using lactose in sweet whey (González Siso, 1996); however, further work is required to extrapolate these studies to acid whey.

\section{ACID WHEY AND HEALTH BENEFITS}

During recent years, whey fractions have gained significant attention due to their advantages in terms of health benefits and diverse applications. Proteins, lipids, lactose, and bioactive molecules derived from whey have been reported to hold potential biotechnological capacity and promise for use in the health sector. In this review, the impact of acid whey from Greek yogurt and cottage cheese on human health and potential applications to ameliorate disease are described.

\section{Acid Whey Proteins}

In recent years, whey proteins have been used as a supplement due to the multiple health benefits reported (Arla Foods Ingredients, 2019). The bioactivity of whey proteins is directly related to their structural properties. They can act as a complete molecule or as partially hydrolyzed or small bioactive peptides. The bioactivity effects and efficacy of whey proteins have been studied in both animal and human models. These beneficial effects include improved digestibility and reduction of chronic disease risk, among others. For these reasons and more, acid whey proteins have potential applications for commercialization in the market. The diversity in applications and health benefits envisage more acid whey-based products in the future. The most abundant acid whey proteins reported are $\beta$-lactoglobulin, $\alpha$-lactalbumin, lactoferrin, immunoglobulins, bovine serum albumin, and lysozyme, among others. However, in this review, we will address the health benefits of $\alpha$-lactalbumin and lactoferrin proteins that have been isolated directly from acid whey.

$\alpha$-Lactalbumin. $\alpha$-Lactalbumin comprises around 13 to $19 \%$ of the total acid whey proteins. This protein is made up of essential amino acids, including lysine, tryptophan, leucine, and sulfur-amino acids (cysteine and methionine). Different methods have been used to purify $\alpha$-LA from acid whey, including cation-exchange chromatography and HPLC. Through cation-exchange chromatography, using food-grade buffers, $\alpha$-LA was purified with $93 \%$ purity and $90 \%$ recovery (Turhan and Etzel, 2004). On the other hand, using HPLC was possible, purifying the $\alpha$-LA from camel milk acid whey, with $86.6 \%$ recovery (Elkot, 2019). Health benefits have been reported from bovine $\alpha$-LA. For example, $\alpha$-LA can bind to oleic acid, forming a complex called BAMLET, and in the case of human protein, HAMLET. These complexes are reported to have anticancer properties through the killing of tumoral cells, induction of lysosomal destabilization, and promotion of the cell death pathway. BAMLET complexes may be a new therapeutic option for aggressive forms of cancers (Rammer et al., 2010). In addition, $\alpha$-LA contributes to infant and adult nutrition. In infant formula, $\alpha$-LA improves the immune response, promotes intestinal health, and increases nutrient absorption, particularly of iron and zinc. In adults, $\alpha$-LA proteolysis produces bioactive peptides with antibacterial and prebiotic properties, and also increases protein in skeletal muscle (Layman et al., 2018). So far, the use of $\alpha$-LA isolated from acid whey it has not been completely explored. However, in the future, a system for the purification and use of $\alpha$-LA for human consumption could be implemented.

Lactoferrin. Lactoferrin ( $\mathbf{L F})$ is a globular protein, representing between 1 and $2 \%$ of acid whey proteins, and is one of the most important milk proteins, with multifunctional activities. Lactoferrin is a glycoprotein with a $77-\mathrm{kDa}$ molecular mass and an isoelectric point of 7.9 (Smithers, 2015; Guo and Wang, 2016). Acid whey from cheese has been used to isolate LF using monolithic ion-exchange chromatography (Convective Interaction Media, BIA Separations, Ajdovscina, Slovenia). The purified LF proprieties and characteristics, such as iron-binding capacity and antibacterial activity, were not modified (Matijašić et al., 2020). The conclusion of this report is that acid whey as a by-product is a good source of LF production with high added value. Many reports have described the antibacterial activity of LF. Both variants have antibacterial activity against gram-positive, gram-negative, and yeast microorganisms (Ward et al., 2005). To induce bacterial death, 
LF recognizes molecules such as lipopolysaccharide in gram-negative bacteria and lipoteichoic acid in grampositive strains (Rosa et al., 2017). Another bioactivity attributed to LF is in brain function. Supplementation with LF can modulate morphological characteristics of rat hippocampal neurons (Waworuntu et al., 2016). Combined supplementation of LF, milk fat globule membrane (MFGM), and prebiotics has also been shown to increase total spine density in the hippocampus due to accumulation of thin and mushroom spine types (classified using a common system that incorporates head diameter, spine length, and neck diameter; Waworuntu et al., 2016). Others have investigated how maternal supplementation of LF could promote brain development in intrauterine growth-restricted infants through changes in neuronal density (Somm et al., 2014). With maternal LF supplementation, the levels of brain-derived neurotrophic factor (BDNF) and neuronal density recovered to normal levels. Therefore, even maternal LF supplementation could protect neuronal development in offspring and may be a useful nutritional intervention in the future (Somm et al., 2014).

Additionally, LF enzymatic hydrolysis produces a small cationic peptide, lactoferricin, which is several times more active than LF (Ward et al., 2005). Although it is not a naturally occurring peptide, artificial production of the small peptide lactoferrampin from LF shows a broad spectrum of antimicrobial activity against yeast, fungi, viruses, protozoa, and gram-positive and gram-negative bacteria (Haney et al., 2009). In general, LF supplementation in the diet increases energy balance and metabolism and reduces adiposity (Zapata et al., 2017).

\section{Acid Whey Lipids}

Although regarded for its low lipid content, acid whey holds significant potential as a valuable source of health-promoting milk phospholipids (MPL). In acid whey, MPL are found in the form of MFGM fragments, small fat globules, and lipoproteins (Rombaut et al., 2007). In fact, some acid whey by-products, such as acid buttermilk cheese whey, contains as high as $0.39 \%$ lipids and $0.1 \%$ MPL, which is up to 5 times the MPL content in sweet whey (Rombaut et al., 2007). Before its use in other applications, acid whey is clarified to remove these lipids, which cause undesirable turbidity (Rombaut et al., 2006). This concentrated lipid fraction from acid whey has potential for development into valorized MPL-containing ingredients to promote human health.

Using acid whey as a source of MPL has some advantages. Unlike other sources noted for their MPL content, such as buttermilk and butter serum, acid whey is absent of casein, which can facilitate the MPL purification process. In other dairy streams, purification of MPL by ultrafiltration is not suitable, because the MFGM fragments are roughly the same size as the casein molecules (Rombaut et al., 2006). However, because acid whey is casein-free, filtration methods are suitable for purification. The main disadvantage of using acid whey as a source of MPL is that phospholipid content is relatively low compared with other dairy streams (e.g., buttermilk).

Phospholipid Composition. Although acid whey is low in lipid content, the most notable lipid components are MPL. Milk phospholipids generally contain a glycerol or sphingosine backbone esterified to one or more fatty acids that are attached to a phosphate-containing polar head group (i.e., choline, ethanolamine, inositol, serine) at the sn-3 position. The prominent MPL found in acid whey include phosphatidylcholine, phosphatidylethanolamine, phosphatidylinositol, phosphatidylserine, and sphingomyelin (SM). Few studies have reported the MPL composition of acid whey from cheese, which is summarized in Table 3. In general, phosphatidylcholine, phosphatidylethanolamine, and SM are the major MPL in CAW, which are found in similar proportions to in raw milk. It is likely that some variation in the composition and content of MPL in acid whey is a result of differences in cheese type, starting fat content of the milk, treatment of milk and whey, storage time, bacterial starter cultures, analytical methods, and more (Smith et al., 2016). At the time of this publication, no literature has reported the MPL composition of GAW, but it is speculated that GAW will have a similar composition to that from cheese, and that MPL content will also be affected by similar factors.

Health Benefits of the Lipid Fraction. Few studies have directly investigated the health benefits of the lipid fraction of acid whey; however, growing evidence indicates that MPL, irrespective of source, offer significant human health benefits. Specifically, MPL have been noted for their roles in neuronal health and development, gut barrier function, cholesterol absorption and lipid metabolism, inflammation, skin health, and cancer-fighting properties (Anto et al., 2020; Fontecha et al., 2020). Here, we provide some brief highlights on the health benefits of MPL, as these topics have been extensively reviewed in other literature (Rombaut and Dewettinck, 2006; Norris et al., 2019).

Dietary MPL, and particularly SM, are noted for their role in neuronal signaling and cognitive development, as the myelin sheath that surrounds and insulates neurons contains high amounts of SM and its metabolites. Moreover, upon inhibition of de novo sphingolipid synthesis, dietary SM supplementation recovered a loss 
Table 3. Phospholipid composition (mean $\pm \mathrm{SD}$ ) of fresh cheese acid whey

Phospholipid composition in acid whey

\begin{tabular}{llll}
\cline { 2 - 4 } Item & $\begin{array}{l}\text { Spray-dried acid whey powder } \\
\text { from skim milk-based } \\
\text { cottage cheese }\end{array}$ & $\begin{array}{l}\text { Untreated acid buttermilk } \\
\text { quark cheese whey }\end{array}$ & $\begin{array}{l}\text { Untreated acid buttermilk } \\
\text { quark cheese whey }\end{array}$ \\
\hline Total lipids (g/100 $\mathrm{g})$ & $1.0 \pm 0.42$ & $0.39 \pm 0.01$ & $\mathrm{NR}^{1}$ \\
Total polar lipids $(\mathrm{PL})$ & $232 \pm 118 \mathrm{mg} / \mathrm{kg}$ of powder & $99 \pm 1 \mathrm{mg} / 100 \mathrm{~g}$ & $110 \pm 1 \mathrm{mg} / 100 \mathrm{~g}$ \\
Phosphatidylcholine & $28 \pm 16 \mathrm{mg} / \mathrm{kg}$ of powder & $25.8 \pm 1.7 \mathrm{~g} / 100 \mathrm{~g}$ of PL & $24.7 \pm 1.1 \mathrm{~g} / 100 \mathrm{~g}$ of PL \\
Phosphatidylethanolamine & $85 \pm 99 \mathrm{mg} / \mathrm{kg}$ of powder & $30.7 \pm 1.6 \mathrm{~g} / 100 \mathrm{~g}$ of PL & $29.5 \pm 4.2 \mathrm{~g} / 100 \mathrm{~g}$ of PL \\
Phosphatidylinositol & $\mathrm{NR}$ & $9.4 \pm 1.4 \mathrm{~g} / 100 \mathrm{~g}$ of PL & $11.7 \pm 3.7 \mathrm{~g} / 100 \mathrm{~g}$ of PL \\
Phosphatidylserine & $\mathrm{NR}$ & $5.7 \pm 0.4 \mathrm{~g} / 100 \mathrm{~g}$ of PL & $5.4 \pm 0.8 \mathrm{~g} / 100 \mathrm{~g}$ of PL \\
Sphingomyelin & $\mathrm{NR}$ & $21.9 \pm 1.0 \mathrm{~g} / 100 \mathrm{~g}$ of PL & $21.5 \pm 2.3 \mathrm{~g} / 100 \mathrm{~g}$ of PL \\
Analytical method & Thin-layer chromatography & HPLC-ELSD & HPLCLSD \\
Reference & Mavroupoulou and Kosikowski & Rombaut et al. $(2007)$ & Rombaut and Dewettinck $(2007)$ \\
& (1973) & & \\
\hline
\end{tabular}

${ }^{1} \mathrm{NR}=$ not reported

${ }^{2}$ Value reported as total lipid-bound phosphorus.

${ }^{3} \mathrm{HPLC}$ with evaporative light scattering detector.

in brain weight and myelination in rats (Oshida et al., 2003). In human infants born prematurely, with very low birth weight, SM supplementation also improved infant performance in behavioral, cognitive, and motor capacity tests (Tanaka et al., 2013). The neurological benefits of MPL may also apply to age-related diseases, such as Alzheimer's disease, Parkinson's disease, and schizophrenia, which are associated with altered brain phospholipid metabolism (Díaz et al., 2018; Ojo et al., 2019).

The effects of MPL on the gut merge several important aspects of gut health: the intestinal barrier, gut microbiota, and mucosal immunity. Milk phospholipids have been reported to increase crypt depth in the intestine of young artificially reared rats and mice fed a high-fat diet (Milard et al., 2019). Additionally, dietary SM reduces circulating lipopolysaccharide in high-fat diet mice (Norris et al., 2017). Supplementation with MPL also has been reported in some studies to increase the Bifidobacterium abundance in the gut, potentially through a prebiotic-like mechanism (Norris et al., 2017; Milard et al., 2019).

Studies focused on the effects of MPL on the skin barrier also have shown that continuous oral supplementation or topical application of MPL improves skin health through measures such as skin hydration, water-holding capacity, and recovery of damaged skin (Higurashi et al., 2015; Lee et al., 2020). Demonstrated by the vast health benefits of MPL, acid whey may be an interesting source of MPL for further purification.

Processing Techniques for Purification of Acid Whey Phospholipids. Whether acid whey is derived from Greek yogurt or fresh cheese production, it can be further processed for purification of health-promoting phospholipids. Figure 2 shows a general processing schematic to obtain phospholipid-enriched ingredients from acid whey resulting from Greek yogurt or fresh cheese production. In brief, raw materials such as pasteurized milk or buttermilk can be used for production of Greek yogurt or cheese, resulting in acid whey that appears turbid from the presence of milk lipids. To collect this lipid fraction, either thermocalcic aggregation or microfiltration is typically performed. Thermocalcic aggregation is a defatting process of precipitating lipids through means of calcium addition, increasing the $\mathrm{pH}$, and the application of heat, resulting in a white lipid precipitate and clear, yellowish acid whey (Rombaut and Dewettinck, 2007). According to the findings of Rombaut et al. (2006), thermocalcic aggregation results in precipitation of about $7.3 \%$ of the unclarified whey mass, containing MFGM fragments, minerals, and denatured whey proteins. The authors later reported an optimized procedure for thermocalcic aggregation with a recovery of $91 \%$ acid whey MPL using a calcium content of $0.205 \mathrm{~g}$ of $\mathrm{Ca}^{2+} / \mathrm{L}$ of whey, temperature of $55^{\circ} \mathrm{C}$, and $\mathrm{pH}$ of 7.7 (Rombaut and Dewettinck, 2007). The driving factor of MPL recovery was $\mathrm{pH}$, over changes in temperature and calcium content. The final polar lipid concentration on pellet dry matter obtained was $8.34 \%$. However, the high mineral content of the phospholipid-enriched sludge makes it less suitable for further purification.

Microfiltration may be a useful alternative to enrich MPL in acid whey, due to the lack of casein particles. This lack of casein could facilitate the purification of MFGM fragments that is typically limited by the similar size of casein molecules. Through manipulation of $\mathrm{pH}$, membrane type, and incorporation of diafiltration, Rombaut et al. (2007) achieved a polar lipid content of $6.79 \mathrm{~g} / 100 \mathrm{~g}$ of dry matter. A negatively charged 
membrane exhibited higher flux and less fouling than other membrane types, and increasing the $\mathrm{pH}$ to 7.5 achieved an additional reduction in membrane fouling. In addition, a membrane pore size of less than $0.15 \mu \mathrm{m}$ minimized loss of MFGM fragments.

Ultimately, acid whey is a suitable candidate for further purification of MPL. Milk phospholipids have been shown to promote human health through improving gut barrier integrity, neurological function, and postprandial lipid metabolism (Castro-Gómez et al., 2015; Ortega-Anaya and Jiménez-Flores, 2019). However, there is a significant lack of available literature on the composition and content of MPL in GAW, the health benefits of MPL derived directly from acid whey, and how we can further optimize the MPL-enrichment process for use as novel ingredients.

\section{Organic Acids}

Many organic acids can be found in dairy products, such as orotic, citric, pyruvic, lactic, uric, formic, acetic, propionic, and hippuric acids (Marsili et al., 1981). However, one of the most characteristic components in acid whey is lactic acid, a compound obtained from the fermentation of lactose by bacterial cultures during the production of cream cheese, strained yogurt, and casein through milk acidification (Chen et al., 2016). Acid whey can contain up to 16 times the concentration of lactic acid found in sweet whey (Riera Rodríguez et al., 2012). This elevated content of lactic acid complicates the spray-drying process due to the hygroscopic nature of lactate ions (Chandrapala and Vasiljevic, 2017). Traditionally, lactic acid has been considered only as a metabolite that can affect the organoleptic and antimi- crobial properties of food; however, research has shown that it may have many bioactive properties.

For example, a study comparing the effects of lactic and citric acid on salivation showed that food containing lactic acid, such as yogurt, promoted salivary secretion, and that this effect was stronger than the response to citric acid (Murugesh et al., 2015) Thus, yogurt was proposed as a potential candidate in the treatment of dry mouth. After ingestion, lactic acid fortification has been shown to promote calcium absorption in rats treated with omeprazole, an over-the-counter medication that acts as a proton pump inhibitor (Chonan et al., 1998a). Moreover, similar effects were found in gastrectomized rats, leading to the hypothesis that lactic acid may be associated with an increased dissolution of water-insoluble forms of calcium, thus increasing their bioavailability (Chonan et al., 1998b). Other beneficial effects of lactic acid are related to adipose tissue metabolism. Research has shown that lactic acid may have a role in reducing lipolysis in human and rat adipose tissues. This reduction was first demonstrated by ex vivo experiments on fat pads from Sprague-Dawley rats, where incubation with lactate resulted in a lower outflow of free fatty acids from fat deposits (Björntorp, 1965). Clinical trials on exercising men showed lower free fatty acid and glycerol levels in plasma after infusion of sodium lactate compared with saline infusions, confirming lactic acid involvement in adipose tissue metabolism. Thus, it was hypothesized that the presence of plasma lactate may serve as a signal to fat cells to decrease lipolysis, because free fatty acids cannot be utilized anaerobically by muscle cells (Boyd et al., 1974). Further experiments on cell lines and fat pads from mice also showed a reduction in adipose lipolysis

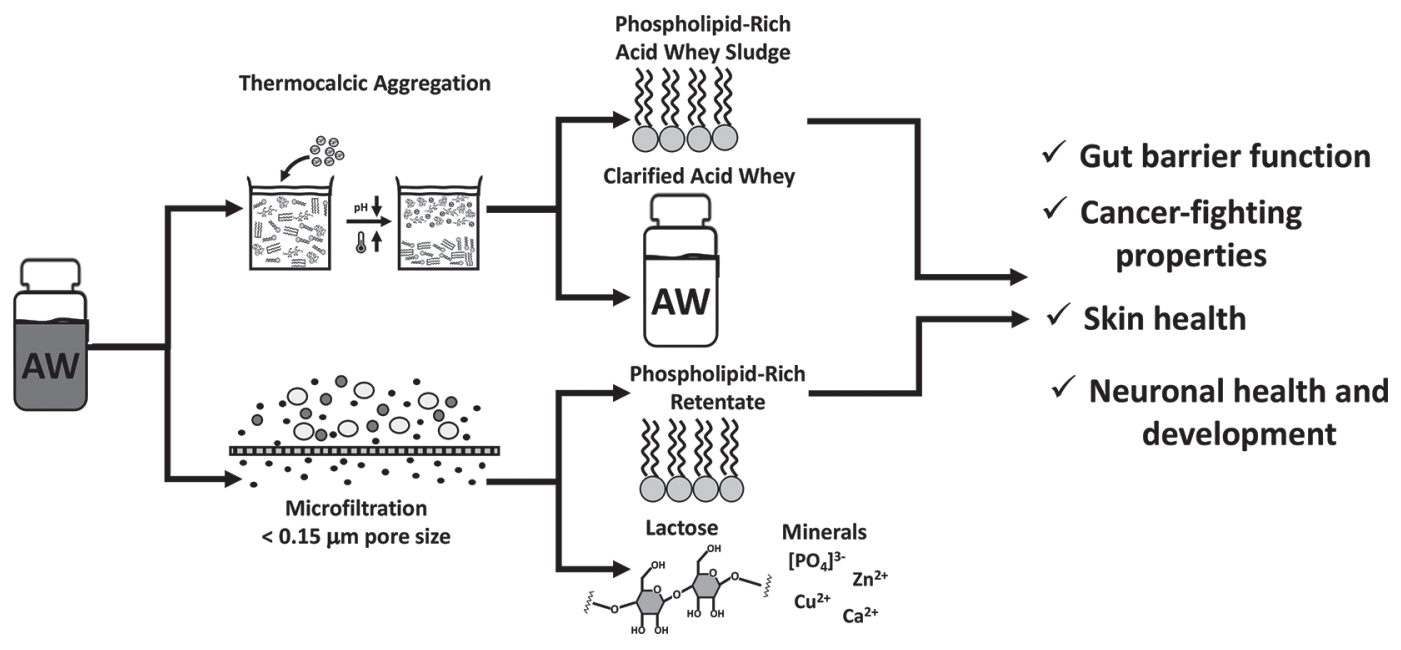

Figure 2. Outline of processing to obtain phospholipids-enriched ingredients from acid whey (AW). 
by lactic acid, and that the stimulation of the GPCR GPR81 $\mathrm{G}_{\mathrm{i}}$-coupled receptor, using a similar mechanism to the one proposed for niacin, achieved this effect (Cai et al., 2008). This finding potentially explains the lower free fatty acid content reported for exercising men. This reduction in adipose tissue lipolysis is of special interest in conditions such as pulmonary and circulatory insufficiency, as well as obesity and physical training (Björntorp, 1965).

Moreover, lactic acid has been shown to have antiinflammatory properties in macrophage-like THP-1 (Watanabe et al., 2009) and RAW 264.7 cells (Kellum et al., 2004). Interestingly, in both cases, this antiinflammatory effect was not related to the $\mathrm{pH}$-lowering effect of lactic acid but to an interference in inflammatory signaling pathways triggered by lipopolysaccharide-induced phosphorylation of extracellular signalregulated kinase and inhibitor of nuclear factor $\kappa \mathrm{B}-\alpha$ (I- $\kappa \mathrm{B}-\alpha$; Watanabe et al., 2009), and decreased levels of lipopolysaccharide-induced nitric oxide, IL-6, and IL-10 (Kellum et al., 2004).

Other bioactive properties are related to topical applications of lactic acid in cosmetic creams. Results showed reduced overall severity of photodamage, mottled hyperpigmentation, and sallowness, and improvements in skin smoothness in response to lactic acid (Smith, 1996). These effects were related to an inhibition of melatonin formation in melanocytes through the inhibition of their tyrosinase activity (Usuki et al., 2003) and the promotion of cell apoptosis in keratinocytes (Hsiao et al., 2009). Lactic acid has further bioactive properties in the body related to the stimulation of endothelial cell migration (Beckert et al., 2006), inhibition of germ cell apoptosis in the human testis (Erkkilä et al., 2002), amelioration of cognitive impairment (Holloway et al., 2007), and improvement of cerebral energy metabolism in humans with traumatic brain injury (Bouzat et al., 2014).

\section{CONCLUSIONS}

Whether from Greek yogurt, cottage cheese, or other soft cheeses produced by fermentation, each type of acid whey presents different challenges due to its mineral composition and varied protein and lactose contents. However, careful analysis of acid whey composition, properties, and potential leads us to believe that it has very high value that has yet to be tapped. Perhaps the way to commercialization and valorization of acid whey rests in two fundamental developments. First, a more scientific and fundamental understanding of acid whey as a whole matrix or on each of its components is needed. For example, a better understanding of the role of lactose in nutrition or how the whey would help a variety of fermentations to produce high-value components. Second, just as was the case for whey protein, we need better ways to measure the usefulness of the acid whey components. In the case of sweet whey, the advent of means to measure the functional properties of whey proteins (foaming, emulsification, and others) gave us means to objectively valorize them. It is evident that the valorization of acid whey will have to be very different than the path that sweet whey followed. Commercialization of whey protein has been the hallmark of sweet whey, and this process has taught us valuable lessons on the environmental impact of valorization strategies as we wait for better solutions for the permeate produced. We propose, in conclusion, that acid whey components, novel processes, and knowledge of their effects in nutrition and human health will show us the way to its optimal utilization, valorization, and concomitant benefit to the dairy industry.

\section{ACKNOWLEDGMENTS}

This research was funded by the Parker Endowment at Ohio State University, Columbus, grant number 00100. The authors thank Molly J. Davis (Department of Food Science and Technology, The Ohio State University, Columbus) for editing the manuscript. The authors have not stated any conflicts of interest.

\section{REFERENCES}

Almécija, M. C., A. Guadix, A. Martinez-Ferez, P. González-Tello, and E. M. Guadix. 2009. A flux enhancing pretreatment for the ultrafiltration of acid whey. Desalination 245:737-742. https://doi .org/10.1016/j.desal.2009.02.045.

Alsaed, A. K., R. Ahmad, H. Aldoomy, S. Abd El-Qad, D. Saleh, H. Sakejha, and L. Mustafa. 2013. Characterization, concentration and utilization of sweet and acid whey. Pak. J. Nutr. 12:172-177. https://doi.org/10.3923/pjn.2013.172.177.

Alsaed, A. K., and M. Hadadin. 2012. Utilization of acidic labneh whey lactose hydrolysed syrup in baking and confectionery. Pak. J. Nutr. 11:688-695. https://doi.org/10.3923/pjn.2012.786.793.

Andrew, T. R. 1977. Chapter 18: Applications of xanthan gum in foods and related products. Pages 231-241 in Extracellular Microbial Polysaccharides. ACS Symposium Series. P. A. Sandford and A. Laskin, ed. American Chemical Society, Washington, DC. https:// doi.org/https://doi.org/10.1021/bk-1977-0045.ch018.

Anema, S. G. 2009. Stability of milk-derived calcium phosphate suspensions. Dairy Sci. Technol. 89:269-282. https://doi.org/10.1051/ dst/2009005.

Anto, L., S. W. Warykas, M. Torres-Gonzalez, and C. N. Blesso. 2020 Milk polar lipids: Underappreciated lipids with emerging health benefits. Nutrients 12:1001. https://doi.org/10.3390/nu12041001.

Arla Foods Ingredients. 2019. Acid whey isn't waste-It's a goldmine, says Arla Foods Ingredients. Accessed Aug. 22, 2019. https://www .arlafoodsingredients.com/about/press-centre/2016/pressrelease/ acid-whey-isn-t-waste-it-s-a-goldmine-says-arla-foods-ingredients $-1422934 /$.

Astley, M. 2013. Chobani, Dannon attempt to defuse Greek yogurt "acid whey" environmental concerns. Accessed May 30, 2013. https: / / www.foodnavigator-usa.com/Article/2013/05/27/Chobani -Dannon-attempt-to-defuse-Greek-yogurt-acid-whey-concerns. 
Beckert, S., F. Farrahi, R. S. Aslam, H. Scheuenstuhl, A. Königsrainer, M. Z. Hussain, and T. K. Hunt. 2006. Lactate stimulates endothelial cell migration. Wound Repair Regen. 14:321-324. https://doi .org/10.1111/j.1743-6109.2006.00127.x.

Benaissa, M., H. Zadi-Karam, and N. Karam. 2017. Development of a sweet whey-based medium for culture of Lactobacillus. Afr. J. Biotechnol. 16:1630-1637. https://doi.org/10.5897/AJB2017.16088.

Björntorp, P. 1965. The effect of lactic acid on adipose tissue metabolism in vitro. Acta Med. Scand. 178:253-255. https://doi.org/10 $.1111 /$ j.0954-6820.1965.tb04268.x.

Bouzat, P., N. Sala, T. Suys, J. B. Zerlauth, P. Marques-Vidal, F. Feihl, J. Bloch, M. Messerer, M. Levivier, R. Meuli, P. J. Magistretti, and M. Oddo. 2014. Cerebral metabolic effects of exogenous lactate supplementation on the injured human brain. Intensive Care Med. 40:412-421. https://doi.org/10.1007/s00134-013-3203-6.

Boyd, A. E. III, S. R. Giamber, M. Mager, and H. E. Lebovitz. 1974. Lactate inhibition of lipolysis in exercising man. Metabolism 23:531-542. https://doi.org/10.1016/0026-0495(74)90081-X.

Bylund, G. 2015. Dairy Processing Handbook. 3rd. ed. Tetra Pak Processing Systems AB, Lund, Sweden.

Cai, T. Q., N. Ren, L. Jin, K. Cheng, S. Kash, R. Chen, S. D. Wright, A. K. P. Taggart, and M. G. Waters. 2008. Role of GPR81 in lactate-mediated reduction of adipose lipolysis. Biochem. Biophys. Res. Commun. 377:987-991. https://doi.org/10.1016/j.bbrc.2008 .10 .088 .

Castro-Gómez, P., A. Garcia-Serrano, F. Visioli, and J. Fontecha. 2015. Relevance of dietary glycerophospholipids and sphingolipids to human health. Prostaglandins Leukot. Essent. Fatty Acids 101:41-51. https://doi.org/10.1016/j.plefa.2015.07.004.

Chandrapala, J., M. C. Duke, S. R. Gray, M. Weeks, M. Palmer, and T. Vasiljevic. 2016. Nanofiltration and nanodiafiltration of acid whey as a function of $\mathrm{pH}$ and temperature. Separ. Purif. Tech. 160:18-27. https://doi.org/10.1016/j.seppur.2015.12.046.

Chandrapala, J., and T. Vasiljevic. 2017. Properties of spray dried lactose powders influenced by presence of lactic acid and calcium. J. Food Eng. 198:63-71. https://doi.org/10.1016/j.jfoodeng.2016 .11 .017 .

Chen, G. Q., F. I. I. Eschbach, M. Weeks, S. L. Gras, and S. E. Kentish. 2016. Removal of lactic acid from acid whey using electrodialysis. Separ. Purif. Tech. 158:230-237. https://doi.org/10.1016/j .seppur.2015.12.016.

Chonan, O., R. Takahashi, H. Yasui, and M. Watanuki. 1998a. Effect of L-lactic acid on calcium absorption in rats fed omeprazole. J. Nutr. Sci. Vitaminol. (Tokyo) 44:473-481. https://doi.org/10 $.3177 /$ jnsv. 44.473 .

Chonan, O., R. Takahashi, H. Yasui, and M. Watanuki. 1998b. Effect of L-lactic acid on the absorption of calcium in gastrectomized rats. J. Nutr. Sci. Vitaminol. (Tokyo) 44:869-875. https://doi.org/ 10.3177/jnsv.44.869.

Coté, A., W. A. Brown, D. Cameron, and G. P. van Walsum. 2004. Hydrolysis of lactose in whey permeate for subsequent fermentation to ethanol. J. Dairy Sci. 87:1608-1620. https://doi.org/10 .3168/jds.S0022-0302(04)73315-9.

Crowley, S. V., M. S. Molitor, R. Kalscheuer, Y. Lu, A. L. Kelly, J. A. O'Mahony, and J. A. Lucey. 2019. Size classification of precipitated calcium phosphate using hydrocyclone technology for the recovery of minerals from deproteinised acid whey. Int. J. Dairy Technol. 72:142-151. https://doi.org/10.1111/1471-0307.12570.

Das, B., S. Sarkar, S. Maiti, and S. Bhattacharjee. 2016. Studies on production of ethanol from cheese whey using Kluyveromyces marxianus. Mater. Today Proc. 3:3253-3257. https://doi.org/10 $.1016 /$ j.matpr.2016.10.006

De La Cruz, L., and T. Saint-Denis. 2016. Acid whey with stable lactose content. Assignee: Compagnie Gervais Danone, France. U. S. Patent No. WO 2016/177701 Al.

De Wit, J. N. 2011. Chapter 7: Applications of whey products. Pages 40-72 in Lecturer's Handbook on Whey and Products. European Whey Products Association. Accessed Apr. 22, 2020. http://ewpa .euromilk.org/fileadmin/user_upload/Public_Documents/EWPA _Publications/Lecturer_s_Handbook_on_Whey.pdf.

Despain, D. 2013. Restarting breakfast. Food Technol. 67:69-80.
Díaz, M., N. Fabelo, I. Ferrer, and R. Marín. 2018. "Lipid raft aging" in the human frontal cortex during nonpathological aging: Gender influences and potential implications in Alzheimer's disease. Neurobiol. Aging 67:42-52. https://doi.org/10.1016/j.neurobiolaging .2018.02.022.

Diniz, R. H. S., M. Q. R. B. Rodrigues, L. G. Fietto, F. M. L. Passos, and W. B. Silveira. 2014. Optimizing and validating the production of ethanol from cheese whey permeate by Kluyveromyces marxianus UFV-3. Biocatal. Agric. Biotechnol. 3:111-117. https:/ /doi.org/10.1016/j.bcab.2013.09.002.

Dudkiewicz, M., J. Berlowska, and D. Kregiel. 2016. Acid whey as a medium for cultivation of conventional and non-conventional yeasts. Biotech. Food Sci. 80:75-82. http://www.bfs.p.lodz.pl.

Dufton, G., S. Mikhaylin, S. Gaaloul, and L. Bazinet. 2018. How electrodialysis configuration influences acid whey deacidification and membrane scaling. J. Dairy Sci. 101:7833-7850. https://doi.org/10 $.3168 /$ jds.2018-14639.

Elkot, W. F. 2019. Characterization and healthier properties of whey proteins of camel milk: A review. J. Agroaliment. Processes Technol. 25:79-88.

Erickson, B. 2017. Acid whey: Is the waste product an untapped goldmine? Accessed Feb. 6, 2017. https://cen.acs.org/articles/95/i6/ Acid-whey-waste-product-untapped.html.

Erkkilä, K., H. Aito, K. Aalto, V. Pentikäinen, and L. Dunkel. 2002. Lactate inhibits germ cell apoptosis in the human testis. Mol. Hum. Reprod. 8:109-117. https://doi.org/10.1093/molehr/8.2.109.

Fontecha, J., L. Brink, S. Wu, Y. Pouliot, F. Visioli, and R. JiménezFlores. 2020. Sources, production, and clinical treatments of milk fat globule membrane for infant nutrition and well-being. Nutrients 12. https://doi.org/10.3390/nu12061607.

González, T., and E. B. Smith. 2014. Soluble fiber from yogurt whey. Assignee: General Mills, Inc., Minneapolis, MN (US). U. S. Patent No. 20140348979.

González Siso, M. I. 1996. The biotechnological utilization of cheese whey: A review. Bioresour. Technol. 57:1-11. https://doi.org/10 .1016/0960-8524(96)00036-3.

Guimarães, P. M. R., J. A. Teixeira, and L. Domingues. 2010. Fermentation of lactose to bio-ethanol by yeasts as part of integrated solutions for the valorisation of cheese whey. Biotechnol. Adv. 28:375-384. https://doi.org/10.1016/j.biotechadv.2010.02.002.

Guo, M., and G. Wang. 2016. Whey protein polymerisation and its applications in environmentally safe adhesives. Int. J. Dairy Technol. 69:481-488. https://doi.org/10.1111/1471-0307.12303.

Haney, E. F., K. Nazmi, F. Lau, J. G. M. Bolscher, and H. J. Vogel. 2009. Novel lactoferrampin antimicrobial peptides derived from human lactoferrin. Biochimie 91:141-154. https://doi.org/10 .1016/j.biochi.2008.04.013.

Higurashi, S., Y. Haruta-Ono, H. Urazono, T. Kobayashi, and Y. Kadooka. 2015. Improvement of skin condition by oral supplementation with sphingomyelin-containing milk phospholipids in a double-blind, placebo-controlled, randomized trial. J. Dairy Sci. 98:6706-6712. https://doi.org/10.3168/jds.2015-9529.

Holloway, R., Z. Zhou, H. B. Harvey, J. E. Levasseur, A. C. Rice, D. Sun, R. J. Hamm, and M. R. Bullock. 2007. Effect of lactate therapy upon cognitive deficits after traumatic brain injury in the rat. Acta Neurochir. (Wien) 149:919-927. https://doi.org/10 .1007/s00701-007-1241-y.

Hsiao, Y. P., H. L. Huang, W. W. Lai, J. G. Chung, and J. H. Yang. 2009. Antiproliferative effects of lactic acid via the induction of apoptosis and cell cycle arrest in a human keratinocyte cell line (HaCaT). J. Dermatol. Sci. 54:175-184. https://doi.org/10.1016/j .jdermsci.2009.02.012.

Husain, Q. 2010. Beta galactosidases and their potential applications: A review. Crit. Rev. Biotechnol. 30:41-62. https://doi.org/10 .3109/07388550903330497.

Jelen, P. 2011. Whey processing: Utilization and products. Pages 731737 in Encyclopedia of Dairy Sciences. 2nd ed. https://doi.org/10 .1016/B978-0-12-374407-4.00495-7.

Kar, J. R., J. E. Hallsworth, and R. S. Singhal. 2015. Fermentative production of glycine betaine and trehalose from acid whey us- 
ing Actinopolyspora halophila (MTCC 263). Environ Technol Inno 3:68-76. https://doi.org/10.1016/j.eti.2015.02.001.

Kellum, J. A., M. Song, and J. Li. 2004. Lactic and hydrochloric acids induce different patterns of inflammatory response in LPSstimulated RAW 264.7 cells. Am. J. Physiol. Regul. Integr. Comp. Physiol. 286:R686-R692. https://doi.org/10.1152/ajpregu.00564 2003.

Ketterings, Q., K. Czymmek, S. Cmi, G. Godwin, and K. Ganoe. 2017. Guidelines for Land Application of Acid Whey. Accessed Feb. 23, 2017. http://nmsp.cals.cornell.edu/publications/files/ AcidWheyGuidelines2017.pdf.

Kırmaci, H. A., B. H. Özer, M. Akçelik, and N. Akçelik. 2015. Identification and characterisation of lactic acid bacteria isolated from traditional Urfa cheese. Int. J. Dairy Technol. 69:301-307. https:/ /doi.org/10.1111/1471-0307.12260.

Koutinas, A. A., H. Papapostolou, D. Dimitrellou, N. Kopsahelis, E. Katechaki, A. Bekatorou, and L. A. Bosnea. 2009. Whey valorisation: A complete and novel technology development for dairy industry starter culture production. Bioresour. Technol. 100:37343739. https://doi.org/10.1016/j.biortech.2009.01.058.

Layman, D. K., B. Lönnerdal, and J. D. Fernstrom. 2018. Applications for $\alpha$-lactalbumin in human nutrition. Nutr. Rev. 76:444-460. https://doi.org/10.1093/nutrit/nuy004.

Lee, K., S. Kim, A. Kim, H.J. Suh, and K. Hong. 2020. Sphingolipid identification and skin barrier recovery capacity of a milk sphingolipid-enriched fraction (MSEF) from buttermilk powder. Int. J. Cosmet. Sci. 42:270-276. https://doi.org/10.1111/ics.12612.

Lievore, P., D. R. S. Simões, K. M. Silva, N. L. Drunkler, A. C. Barana, A. Nogueira, and I. M. Demiate. 2015. Chemical characterisation and application of acid whey in fermented milk. J. Food Sci. Technol. 52:2083-2092. https://doi.org/10.1007/s13197-013 -1244-z.

Lucas, A., E. Rock, J.-F. Chamba, I. Verdier-Metz, P. Brachet, and J.-B. Coulon. 2006. Respective effects of milk composition and the cheese-making process on cheese compositional variability in components of nutritional interest. Lait 86:21-41. https://doi.org/ 10.1051/lait:2005042.

Marsili, R. T., H. Ostapenko, R. E. Simmons, and D. E. Green. 1981. High performance liquid chromatographic determination of organic acids in dairy products. J. Food Sci. 46:52-57. https://doi.org/ 10.1111/j.1365-2621.1981.tb14529.x.

Matijašić, B. B., J. Oberčkal, P. Mohar Lorbeg, D. Paveljšek, N. Skale, B. Kolenc, S. Gruden, N. Poklar Ulrih, M. Kete, and M. Zupančič Justin. 2020. Characterisation of lactoferrin isolated from acid whey using pilot-scale monolithic ion-exchange chromatography. Processes (Basel) 8:804. https://doi.org/10.3390/pr8070804.

Mavropoulou, I. P., and F. V. Kosikowski. 1973. Composition, solubility, and stability of whey powders. J. Dairy Sci. 56:1128-1134. https://doi.org/10.3168/jds.S0022-0302(73)85321-4.

Menchik, P., T. Zuber, A. Zuber, and C. I. Moraru. 2019. Short communication: Composition of coproduct streams from dairy processing: Acid whey and milk permeate. J. Dairy Sci. 102:3978-3984. https://doi.org/10.3168/jds.2018-15951.

Milard, M., F. Laugerette, A. Durand, C. Buisson, E. Meugnier, E Loizon, C. Louche-Pelissier, V. Sauvinet, L. Garnier, S. Viel, K. Bertrand, F. Joffre, D. Cheillan, L. Humbert, D. Rainteau, P. Plaisancié, L. B. Bindels, A. M. Neyrinck, N. M. Delzenne, and M.-C. Michalski. 2019. Milk polar lipids in a high-fat diet can prevent body weight gain: Modulated abundance of gut bacteria in relation with fecal loss of specific fatty acids. Mol. Nutr. Food Res. 63:e1801078. https://doi.org/10.1002/mnfr.201801078.

Mintel. 2019. Yogurt and Yogurt Drinks-US - November 2019. Accessed May 16, 2020. https://store.mintel.com/yogurt-and-yogurt -drinks-us-november-2019.

Mollea, C., L. Marmo, and F. Bosco. 2013. Chapter 24: Valorisation of cheese whey, a by-product from the dairy industry. Pages 549-588 in Food Industry. I. Mazzalupo, ed. InTech Open, London, UK. https://doi.org/10.5772/53159.

Mondragón-Parada, M. E., M. Nájera-Martínez, C. Juárez-Ramírez, J. Galíndez-Mayer, N. Ruiz-Ordaz, and E. Cristiani-Urbina. 2006.
Lactic acid bacteria production from whey. Appl. Biochem. Biotechnol. 134:223-232. https://doi.org/10.1385/ABAB:134:3:223.

Murugesh, J., R. G. Annigeri, S. A. Raheel, S. Azzeghaiby, M. Alshehri, and O. Kujan. 2015. Effect of yogurt and $\mathrm{pH}$ equivalent lemon juice on salivary flow rate in healthy volunteers-An experimental crossover study. Interv. Med. Appl. Sci. 7:147-151. https://doi .org/10.1556/1646.7.2015.4.3.

Newhart, B. 2018. State of the industry: How Greek yogurt keeps customers coming back. Accessed Dec. 3, 2018. https://www .dairyreporter.com/Article/2018/12/03/State-of-the-industry -How-Greek-yogurt-keeps-customers-coming-back.

Newhart, B. 2019. Cottage cheese "renaissance" heats up in the US. Accessed Jun. 5, 2019. https://www.dairyreporter.com/Article/ 2019/06/04/Cottage-cheese-renaissance-heats-up-in-the-US.

Norris, G., C. Porter, C. Jiang, and C. Blesso. 2017. Dietary milk sphingomyelin reduces systemic inflammation in diet-induced obese mice and inhibits LPS activity in macrophages. Beverages 3:37. https://doi.org/10.3390/beverages3030037.

Norris, G. H., M. Milard, M. C. Michalski, and C. N. Blesso. 2019. Protective properties of milk sphingomyelin against dysfunctional lipid metabolism, gut dysbiosis, and inflammation. J. Nutr. Biochem. 73:108224. https://doi.org/10.1016/j.jnutbio.2019.108224.

Ojo, J. O., M. Algamal, P. Leary, L. Abdullah, B. Mouzon, J. E. Evans, M. Mullan, and F. Crawford. 2019. Converging and differential brain phospholipid dysregulation in the pathogenesis of repetitive mild traumatic brain injury and Alzheimer's disease. Front. Neurosci. 13:103. https://doi.org/10.3389/fnins.2019.00103.

Ortega-Anaya, J., and R. Jiménez-Flores. 2019. Symposium review: The relevance of bovine milk phospholipids in human nutritionEvidence of the effect on infant gut and brain development. J. Dairy Sci. 102:2738-2748. https://doi.org/10.3168/jds.2018-15342.

Oshida, K., T. Shimizu, M. Takase, Y. Tamura, T. Shimizu, and Y. Yamashiro. 2003. Effects of dietary sphingomyelin on central nervous system myelination in developing rats. Pediatr. Res. 53:589593. https://doi.org/10.1203/01.PDR.0000054654.73826.AC.

Pasotti, L., S. Zucca, M. Casanova, G. Micoli, M. G. Cusella De Angelis, and P. Magni. 2017. Fermentation of lactose to ethanol in cheese whey permeate and concentrated permeate by engineered Escherichia coli. BMC Biotechnol. 17:48. https://doi.org/10.1186/ s12896-017-0369-y.

Rama, G. R., D. Kuhn, S. Beux, M. J. Maciel, and C. F. Volken de Souza. 2019. Potential applications of dairy whey for the production of lactic acid bacteria cultures. Int. Dairy J. 98:25-37. https:/ /doi.org/10.1016/j.idairyj.2019.06.012.

Rammer, P., L. Groth-Pedersen, T. Kirkegaard, M. Daugaard, A. Rytter, P. Szyniarowski, M. Høyer-Hansen, L. K. Povlsen, J. Nylandsted, J. E. Larsen, and M. Jäättelä. 2010. BAMLET activates a lysosomal cell death program in cancer cells. Mol. Cancer Ther. 9:24-32. https://doi.org/10.1158/1535-7163.MCT-09-0559.

Riera Rodríguez, F., A. Fernández Martínez, and C. Muro Urista. 2012. Whey: Types, Composition and Health Implications. R. Benitez and G. Ortero, ed. Nova Science Publishers Inc., Hauppauge, NY.

Rombaut, R., J. V. Camp, and K. Dewettinck. 2006. Phospho- and sphingolipid distribution during processing of milk, butter and whey. Int. J. Food Sci. Technol. 41:435-443. https://doi.org/10 $.1111 /$ j.1365-2621.2005.01091.x.

Rombaut, R., V. Dejonckheere, and K. Dewettinck. 2007. Filtration of milk fat globule membrane fragments from acid buttermilk cheese whey. J. Dairy Sci. 90:1662-1673. https://doi.org/10.3168/jds .2006-587.

Rombaut, R., and K. Dewettinck. 2006. Properties, analysis and purification of milk polar lipids. Int. Dairy J. 16:1362-1373. https:// doi.org/10.1016/j.idairyj.2006.06.011.

Rombaut, R., and K. Dewettinck. 2007. Thermocalcic aggregation of milk fat globule membrane fragments from acid buttermilk cheese whey. J. Dairy Sci. 90:2665-2674. https://doi.org/10.3168/jds .2006-711.

Rosa, L., A. Cutone, M. S. Lepanto, R. Paesano, and P. Valenti. 2017. Lactoferrin: A natural glycoprotein involved in iron and inflammatory homeostasis. Int. J. Mol. Sci. 18:1985. https://doi.org/10 $.3390 /$ ijms18091985. 
Ryan, M. P., and G. Walsh. 2016. The biotechnological potential of whey. Rev. Environ. Sci. Biotechnol. 15:479-498. https://doi.org/ 10.1007/s11157-016-9402-1.

Sansonetti, S., S. Curcio, V. Calabrò, and G. Iorio. 2009. Bio-ethanol production by fermentation of ricotta cheese whey as an effective alternative non-vegetable source. Biomass Bioenergy 33:16871692. https://doi.org/10.1016/j.biombioe.2009.09.002.

Shurson, J. 2009. What we know about feeding liquid by-products to pigs. Accessed Feb. 25, 2009. https://thepigsite.com/articles/what -we-know-about-feeding-liquid-byproducts-to-pigs.

Skryplonek, K., I. Dmytrów, and A. Mituniewicz-Małek. 2019. Probiotic fermented beverages based on acid whey. J. Dairy Sci. 102:7773-7780. https://doi.org/10.3168/jds.2019-16385.

Skryplonek, K., and M. Jasińska. 2015. Fermented probiotic beverages based on acid whey. Acta Sci. Pol. Technol. Aliment. 14:397-405. https://doi.org/10.17306/J.AFS.2015.4.39.

Smith, E., W. Wang, and V. Ghosh. 2014. Food products with yogurt whey. Assignee: General Mills, Inc., Minneapolis, MN (US). U. S. Patent No. 20140348981.

Smith, S., T. J. Smith, and M. A. Drake. 2016. Short communication: Flavor and flavor stability of cheese, rennet, and acid wheys. J. Dairy Sci. 99:3434-3444. https://doi.org/10.3168/jds.2015-10482.

Smith, W. P. 1996. Epidermal and dermal effects of topical lactic acid. J. Am. Acad. Dermatol. 35:388-391. https://doi.org/10.1016/ S0190-9622(96)90602-7.

Smithers, G. W. 2015. Whey-ing up the options-Yesterday, today and tomorrow. Int. Dairy J. 48:2-14. https://doi.org/10.1016/j .idairyj.2015.01.011.

Somm, E., P. Larvaron, Y. van de Looij, A. Toulotte, A. Chatagner, M. Faure, S. Métairon, R. Mansourian, F. Raymond, R. Gruetter, B. Wang, S. V. Sizonenko, and P. S. Hüppi. 2014. Protective effects of maternal nutritional supplementation with lactoferrin on growth and brain metabolism. Pediatr. Res. 75:51-61. https://doi .org/10.1038/pr.2013.199.

Sunkesula, V., A. R. A. Hammam, and L. E. Metzger. 2019. Partial demineralization and deacidification of Greek yogurt acid whey by nanofiltration for improving the drying characteristics of Greek yogurt acid whey. J. Dairy Sci. 102(Suppl. 1):M104. (Abstr.)

Tanaka, K., M. Hosozawa, N. Kudo, N. Yoshikawa, K. Hisata, H. Shoji, K. Shinohara, and T. Shimizu. 2013. The pilot study: Sphingomyelin-fortified milk has a positive association with the neurobehavioural development of very low birth weight infants during infancy, randomized control trial. Brain Dev. 35:45-52. https://doi .org/10.1016/j.braindev.2012.03.004.

Terrell, S. L., A. Bernard, and R. B. Bailey. 1984. Ethanol from whey: Continuous fermentation with a catabolite repression-resistant Saccharomyces cerevisiae mutant. Appl. Environ. Microbiol. 48:577-580. https://doi.org/10.1128/AEM.48.3.577-580.1984.

Tricoles, R. 2019. Cottage cheese is the new Greek yogurt. Accessed Mar. 24, 2019. https://www.theatlantic.com/technology/archive/ 2019/03/cottage-cheese-new-greek-yogurt/585487/.

Turhan, K. N., and M. R. Etzel. 2004. Whey protein isolate and $\alpha$-lactalbumin recovery from lactic acid whey using cation-exchange chromatography. J. Food Sci. 69:fep66-fep70. https://doi .org/10.1111/j.1365-2621.2004.tb15511.x.

Usuki, A., A. Ohashi, H. Sato, Y. Ochiai, M. Ichihashi, and Y. Funasaka. 2003. The inhibitory effect of glycolic acid and lactic acid on melanin synthesis in melanoma cells. Exp. Dermatol. 12:43-50. https://doi.org/10.1034/j.1600-0625.12.s2.7.x.

Villarreal, M. 2017. Value added products utilizing acid whey: Development of a fruit yogurt beverage and a sports drink. Master's thesis. Department of Food Science, College of Agriculture and Life Sciences. Cornell University, Ithaca, NY. https://doi.org/10 $.7298 /$ X4XD0ZSP.

Walsh, H. 2014. Functional properties of whey protein and its application in nanocomposite materials and functional foods. $\mathrm{PhD}$ thesis. Department of Nutrition and Food Sciences, College of Agriculture and Life Sciences. University of Vermont, Burlington, VT.

Ward, P. P., E. Paz, and O. M. Conneely. 2005. Multifunctional roles of lactoferrin: A critical overview. Cell. Mol. Life Sci. 62:25402548. https://doi.org/10.1007/s00018-005-5369-8.

Watanabe, T., H. Nishio, T. Tanigawa, H. Yamagami, H. Okazaki, K. Watanabe, K. Tominaga, Y. Fujiwara, N. Oshitani, T. Asahara, K. Nomoto, K. Higuchi, K. Takeuchi, and T. Arakawa. 2009. Probiotic Lactobacillus casei strain Shirota prevents indomethacininduced small intestinal injury: Involvement of lactic acid. Am. J. Physiol. Gastrointest. Liver Physiol. 297:G506-G513. https://doi .org/10.1152/ajpgi.90553.2008.

Watson, E. 2014. Greek yogurt's biggest guns explore creative ways to address acid whey challenge. Accessed Dec. 5, 2014. https://www .dairyreporter.com/Article/2014/12/05/Patent-watch-General -Mills-tackles-Greek-yogurt-acid-whey.

Waworuntu, R. V., T. Hanania, S. R. Boikess, C. S. Rex, and B. M. Berg. 2016. Early life diet containing prebiotics and bioactive whey protein fractions increased dendritic spine density of rat hippocampal neurons. Int. J. Dev. Neurosci. 55:28-33. https://doi.org/ 10.1016/j.ijdevneu.2016.09.001

Wherry, B., D. M. Barbano, and M. A. Drake. 2019. Use of acid whey protein concentrate as an ingredient in nonfat cup set-style yogurt. J. Dairy Sci. 102:8768-8784. https://doi.org/10.3168/jds .2019-16247.

Zapata, R. C., A. Singh, A. Pezeshki, T. Nibber, and P. K. Chelikani. 2017. Whey protein components - lactalbumin and lactoferrinimprove energy balance and metabolism. Sci. Rep. 7:9917. https:/ /doi.org/10.1038/s41598-017-09781-2.

Zotta, T., L. Solieri, L. Iacumin, C. Picozzi, and M. Gullo. 2020. Valorization of cheese whey using microbial fermentations. Appl. Microbiol. Biotechnol. 104:2749-2764. https://doi.org/10.1007/ s00253-020-10408-2.

\section{ORCIDS}

Erica Kosmerl ๑ https://orcid.org/0000-0002-0751-4990

Abigail Krentz @ https://orcid.org/0000-0002-9431-9578

Lin Zhang @ https://orcid.org/0000-0002-8956-2768

Shivani Badiger (ㄴ) https://orcid.org/0000-0001-8122-699X

Gonzalo Miyagusuku-Cruzado ( ) https://orcid.org/0000-0002-4420 $-6022$

Alba Mayta-Apaza @ https://orcid.org/0000-0001-8721-0788

Monica Giusti (๑ https://orcid.org/0000-0002-2348-3530

Rafael Jiménez-Flores @ (․ https://orcid.org/0000-0003-4905-5021

Israel García-Cano @ https://orcid.org/0000-0003-2891-7286 